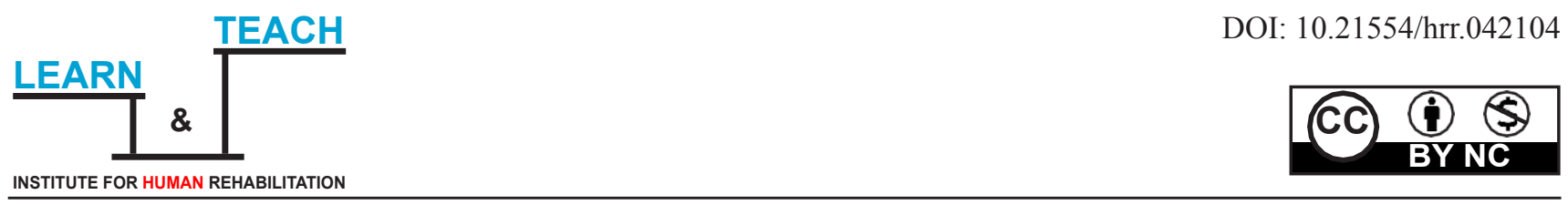

\title{
SENSORY INTEGRATION AND ACTIVITIES THAT PROMOTE SENSORY INTEGRATION IN CHILDREN WITH AUTISM SPECTRUM DISORDERS
}

Original scientific paper

\author{
Aleksandra Basic ${ }^{1}$, Dragana Macesic Petrovic ${ }^{1}$, Ljiljana Pantovic ${ }^{2}$, Ruzica Zdravkovic Parezanovic ${ }^{3}$, \\ Anja Gajic ${ }^{1}$, Bojana Arsic ${ }^{1}$, Jovana Nikolic ${ }^{1}$
}

${ }^{1}$ Faculty of Special Education and Rehabilitation, University of Belgrade, Serbia

${ }^{2}$ Institute for Philosophy and Social Theory, University of Belgrade, Serbia

${ }^{3}$ Logopedilište, Belgrade, Serbia

Received: 2021/3/1

Accepted: 2021/4/5

\begin{abstract}
The aim of this review was to systematically identify, analyze, and summarize research involving interventions based on sensory integration and activities that promote sensory integration in children with ASD. Based on the selection criteria ten out of thirty studies were selected and described in terms of: a) participant characteristics, b) assessments used in the studies, c) intervention procedures, d) study goals, e) intervention outcomes and whether or not there was improvement in behavior or clinical conditions. The results of the analyzed studies indicate a remarkable heterogeneity profile of sensory function in children with ASD, which affect the applicability of different forms of treatment. Based on the results of these studies, we can conclude that treatments based on SI theory can reduce stereotypical, aggressive, auto-aggressive, irritable, and hyperactive behavior, as well as improve self-regulation of behavior.

Keywords: Autism, sensory integration, sensory disorders, therapy, auditory intervention training, sensory intervention therapy
\end{abstract}

\section{INTRODUCTION}

Sensory integration therapy (SIT) or sensory processing therapy (SPT) and activities that promote sensory integration are widely used diagnosing and treating disabilities in children with Autism Spectrum Disorder (ASD). Treatments based on the theory of sensory integration that are most often used in working with people with ASD are sensory integration therapy (SIT), auditory integration training (AIT) and deep pressure therapy (DPT) (Green et al., 2006).

Sensory integration (SI) is a neurological process, also described as Sensory Processing (SP) that allows us to take information we receive from our five senses, organize it, and respond appropriately.
The development of the sensory system begins in the intrauterine period and continues throughout the life of the individual (Mamic, Fulgosi Masnjak, \& Miller, 2010). Sensory system consists of seven areas of sensory modalities: auditory, visual, tactile, olfactory, gustatory, vestibular, and proprioceptive (Mamic \& Fulgosi Masnjak, 2010). Interacting with others and with the environment relies on sensory information we receive through the sensory system (Van Dam, Paris, \& Ernst, 2014). Although cortical structures responsible for receiving, processing, integrating, and interpreting sensory information are the same in all people, the way an individual experiences and responds to external sensa-

Correspondence to:

Aleksandra Bašić, Faculty of Special Education and Rehabilitation, University of Belgrade, Serbia

Belgrade, Serbia

E-mail: aleksandra@fasper.bg.ac.rs 
tions varies from person to person (Sobocko \& Zelens$\mathrm{ki}, 2015)$. The basic capacities of sensory integration are genetically determined; the development of this complex process takes place through interaction with the environment and cerebral and bodily adaptation to external conditions, which is mutually conditioned by adaptive reactions (Macesic-Petrovic, 2014). A child, while interacting with its environment, both physical and social, acquires new and upgrades previous experiences. The quality of these experiences is significantly influenced by the quality of processing information (Bojanin, 2015).

The development of the individual is significantly influenced by the ability to integrate sensory stimuli as one of the key neurobehavioral processes (Fernández-Andrés, Pastor-Cerezuela, Sanz-Cervera \& Tárraga-Mínguez, 2015). Most everyday human activities require multisensory information processing (Hainaut \& Bolmont, 2013) that has a significant impact on the quality of the experience and behavior of the person (Boterberg \& Warreyn, 2016). Typical perceptual experience is characterized by perceptual unity, which is reflected in multisensory integration. At the level of subjective experience this perception is a unique experience, regardless of the characteristics of integrated sensation. Studies have shown that often comes to the modulation process sensory information perception by a sensory perception of other modalities (Bayne, 2014). Adequate sensory integration enables accurate representation of external stimuli, which requires an appropriate orientation in the environment in which we live, adequate perception of the environment and, therefore, a coordinated reaction (Mamic et al., 2010; Panzeri, Harvey, Piasini, Latham, \& Fellin, 2017).

If a person cannot "organize sensory information for use" (Ayres, 1972, p. 4) they can be described as having sensory integration disorder (SID) or sensory processing difficulties. SID or sensory processing difficulties include disorders of perception, modulation, integration and organization of sensory information and the characteristics of the sensory profile of a person with these difficulties are manifested in the adaptive behavior of the individual (Gal, Dyck, \& Passmore, 2010).

According to the theory of sensory integration, sensory processing is the basis of adaptive behavior, learning and socio-cognitive functioning, so it is not surprising that difficulties in sensory processing are manifested in the behavioral, cognitive and social domain, as difficulties in (self) regulation of behavior, planning and motor activities (Jirikowic, Olson, \& Kartin, 2008). Sensory processing difficulties significantly affect the sensory-motor, cognitive and social development of the child, and the effects are observed in a limited ability to function in daily life which affects the quality of life of an individual (Dunn, 1997).

In the DSM-5 classification of the American Psychiatric Association (APA, 2013), autism spectrum disorders (ASD) belong to the group of neurodevelopment disorders. This group of disorders is characterized by persistent deficits in social communication and social interactions, as well as persistence of stereotypical be- havior, repetitive forms of behavior, interests, or activities (Fernández-Andrés et al., 2015). In addition to these basic characteristics, the latest edition of the classification includes the presence of sensory processing difficulties as a diagnostic criterion of ASD (Sanz-Cervera, Pastor-Cerezuela, Fernández-Andrés, \& Tárraga-Mínguez, 2015). Although the first description of ASD includes difficulties in sensory processing, those in earlier classifications were not accepted as a diagnostic criterion, due to the scarcity of empirical evidence, as well as because the focus was on the cognitive and social deficits (Novakovic et al., 2015).

This is a review article of existing research involving interventions based on SIT and activities that promote sensory integration in children with ASD. The aim of this review is to determine if SIT and activities that promote sensory integration can be classified as a scientifically based intervention for children with ASD. Forgoing we examined the effectiveness of procedures and interventions conducted with the goal to enhance sensory integration of children with ASD and doing so we determined if SIT can be classified as a scientifically based intervention for children with ASD.

\section{METHOD}

The service of the Consortium of Libraries of Serbia for Unified Procurement (KOBSON), Google Scholar, SCIndeks, as well as the search engine ScienceDirect were used in the literature review. Literature was searched in both Serbian and English language. The following phrases were used as keywords in the search: sensory processing, sensory processing difficulties, sensory integration, sensory integration therapy, sensory development, and sensory dysfunctions, crossed with the following words: autism, autism spectrum disorders, developmental disorders, developmental disability.

After the initial search, 30 papers were analyzed based on their titles and keywords. Selection criteria henceforward was as follows: that the article dates from 2010 to 2020; that it is not a theoretical article or a review article; that the sample included subjects with ASD; that the topic focuses on the interventions and procedures of sensory integration and / or activities that can encourage sensory integration in children with ASD; that the paper presents activities that promote the sensory integration of children with ASD. Ten articles were selected for this review based on the selection criteria. 


\section{LITERATURE REVIEW RESULTS}

For the purpose of this review ten papers were selected based on previously determined criteria. Table 1 summarizes: a) participant characteristics, b) assessments used in the studies, c) intervention procedures, d) study goals, e) intervention outcomes and whether or not there was improvement in behavior or clinical conditions.

\section{Participants:}

There were a total of 410 subjects in the ten presented studies, $319(77,80 \%)$ of the subjects were diagnosed with ASD, $39(9,51 \%)$ of them had ID, $11(2,68 \%)$ had Asperser's syndrome, $16(3,90)$ were diagnosed with PDD-NOS and $25(6,10)$ had other types of disabilities. As for gender the majority of the subjects were males $338(82,44 \%)$ and $72(17,56 \%)$ were females. Participants ranged in age from 3 to 18 years. Overall, participants involved in these studies were mainly of elementary school age with autism and a large percentage also had moderate to profound ID.

\section{Assessments used:}

Three studies used the Short Sensory Profile (SSP; Dunn, 1999) to confirm the presence of sensory processing issues prior to implementing SIT (Kashefimehr, et al., 2017) or AIT (Brockett, et al., 2014; Al-Ayadhi et al., 2018). SSP is a standardized assessment tool intended for children 3 to 10 years old. It's a 5 point Likert scale with 38 items that measure how the child responds to various sensory stimuli and is usually completed by primary caregivers. Scores are provided in seven categories (tactile sensitivity, taste/smell sensitivity, movement sensitivity, under responsive and seeks sensation, auditory filtering, low energy, and visual and/or auditory sensitivity) intended to identify how a child's nervous system regulates and processes sensory input.

The Sensory Processing Measure (SPM: Glennon, Miller-Kuhaneck, Henry, Parham, \& Ecker, 2007) was used in two studies (Bagatell et al., 2010; Pfeiffer et al., 2011) to identify sensory processing issues and describe them. The assessment tool can be used by primary caregivers and teachers or clinicians. The SPM consists of 75 items (form for primary caregivers) and 62 items (classroom form completed by teachers). Scores are generated into eight standards that describe social participation, vision, hearing, touch, body awareness, balance and motion, planning, and total sensory system and children's sensory processing is classified as "typical", "some problems" or "definite problems". The Childhood Autism Rating Scale (CARS) was used to measure the severity of autism in three of the analyzed studies (Al-Ayadhi et al., 2013; Al-Ayadhi et al., 2018; Wenix et al., 2019). CARS measures 14 dimensions such as interpersonal relationships, emotional responses, adaptation to environmental changes, visual responses, anxiety responses, non-verbal communication, and so on.
The higher the score the severe the condition is.

For example a total score above 30 points can be considered to have autism, whereas those with 30-36 points are divided into mild to moderate autism and those with a score above 36 points with more than 5 indicators achieving 3 or more points can be considered to have severe autism.

Three out of the ten studies used The Social Responsiveness Scale (SRS) to measure interpersonal behavior, communication, and stereotypical traits in autism (Pfeiffer et al. 2011; Al-Ayadhi et al., 2013; Al-Ayadhi et al., 2018). The SRS has five subscales a) social awareness, b) social cognition, c) social communication, d) social motivation, and e) autistic mannerisms. The Autistic Behavior Check List (ABC List) (Lu et al. 2004) was used to determine if a child had autism in two studies (Brockett, et al., 2014; Wenix et al., 2019). This check list has 57 items and the final score is used for evaluation, the higher the score the likelihood of a subject to have autism is higher. For example if the total score is below 31 points, then the subject is considered not to have autism at all. But those with a total score of 53-66 points can be considered to have suspected autism, while if the total score is 67 points or more, then the subject can be considered to have autism.

Pfeiffer et al. (2011) used QNST-II (Mutti et al., 1998) to assess areas including praxis, dexterity, visual tracking, spatial orientation, tactile perception abilities, and motor skills. Vineland Adaptive Behavior Scales, 2nd Edition was used to measure adaptive behavior that assesses the domains of communication, daily living skills, socialization, and motor skills. And the Goal Attainment Scaling was used to determine intervention outcomes expressly relevant to individuals and their families. The goals focused on the three categories of sensory processing, motor skills, and social functioning.

In one study the Autism Treatment Evaluation Checklist (ATEC) was used to evaluate treatment efficiency in subjects with ASD (Ayadhi et al., 2013). This assessment tool is divided into four subscales labeled Speech/ Language/ Communication, Sociability, Sensory/Cognitive Awareness, and Health/ Physical/ Behavior. The subject is more impaired if the subscale and total scores are higher. 


\begin{tabular}{|c|c|c|c|c|c|c|c|}
\hline Citation & $\begin{array}{l}\text { Participant } \\
\text { characteristics }\end{array}$ & Assessment & Intervention/procedure & $\begin{array}{l}\text { The purpose of the } \\
\text { study }\end{array}$ & Results & $\begin{array}{l}\text { There was improvement in } \\
\text { which behaviour }\end{array}$ & $\begin{array}{l}\text { The intervention did not } \\
\text { improve the following } \\
\text { behaviour }\end{array}$ \\
\hline $\begin{array}{l}\text { Al-Ayadhi } \\
\text { et al. (2013) }\end{array}$ & $\begin{array}{l}\text { Total subjects: } \\
72 \text { (M 70/F2) } \\
\text { Dg.: ASD; } \\
\text { Age: } 3 \text { to } 17 \\
\text { yrs. }\end{array}$ & 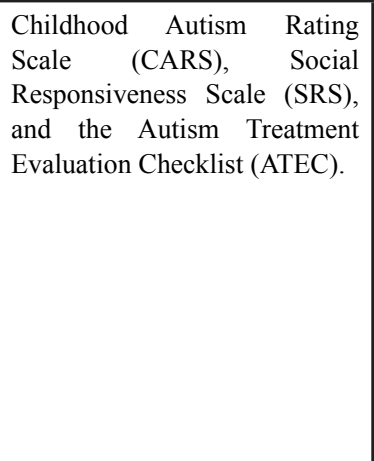 & $\begin{array}{l}\text { Auditory integration training } \\
\text { (AIT). } \\
18 \text { to } 20 \text { listening sessions, lasting } \\
\text { for } 30 \text { minutes, over a } 10 \text { - to } 20- \\
\text { day period in most cases, and had } \\
\text { a } 1 \text { - or 2-day break after } 5 \text { days } \\
\text { of listening. During the listening } \\
\text { sessions, the child listened to } \\
\text { processed music. Overall, the } \\
\text { music was played at a moderately } \\
\text { loud, but not uncomfortable, } \\
\text { level. }\end{array}$ & $\begin{array}{l}\text { The aim of the study } \\
\text { was to determine the } \\
\text { effectiveness of AIT } \\
\text { in people with ASD. }\end{array}$ & $\begin{array}{l}\text { Mixed. } \\
\text { All subjects demonstrated } \\
\text { improvement } 3 \text { and } 6 \text { months } \\
\text { following the AIT. ASD } \\
\text { subject showed } 22 \% \text { and } 26 \% \\
\text { percentage improvement in } \\
\text { SRS scoring } 3 \text { and } 6 \text { months } \\
\text { respectively following the } \\
\text { AIT intervention. }\end{array}$ & $\begin{array}{l}\text { There were statistically } \\
\text { significant changes in social } \\
\text { awareness, social cognition, } \\
\text { and social communication. } \\
\text { Similar results were achieved } \\
\text { with the ATEC checklist: ASD } \\
\text { subjects showed } 19.5 \% \text { and } \\
22.5 \% \text { improvement } 3 \text { and } \\
6 \text { months following the AIT } \\
\text { intervention. Those changes are } \\
\text { due to statistically significant } \\
\text { (P } 0.05) \text { improvement in } \\
\text { speech, communication and } \\
\text { sociability only. }\end{array}$ & $\begin{array}{l}\text { No improvement was } \\
\text { registered in the domain } \\
\text { of social motivation and } \\
\text { stereotypical behaviour, as } \\
\text { well as in the sensory and } \\
\text { cognitive domain. }\end{array}$ \\
\hline $\begin{array}{l}\text { Al-Ayadhi } \\
\text { et al. (2018) }\end{array}$ & $\begin{array}{l}\text { Total: } 15 \\
\text { subjects (M14/ } \\
\text { F1); } \\
\text { Dg::ASD } \\
\text { Age: } 3-12 \\
\text { years. }\end{array}$ & $\begin{array}{l}\text { CARS, Social Responsiveness } \\
\text { Scale (SRS - Constantine, } \\
\text { Gruber, 2007) and the Short } \\
\text { Sensory Profile (SSP) }\end{array}$ & $\begin{array}{l}\text { AIT was performed over } 2 \text { weeks, } \\
\text { for duration of } 30 \text { min, twice a } \\
\text { day with a 3-h interval between } \\
\text { sessions. The listener received } \\
18-20 \text { listening sessions. } \\
\text { The intensity level (volume) } \\
\text { during the AIT listening sessions } \\
\text { did not exceed } 80 \text { dBA (low } \\
\text { scale) and was set at much } \\
\text { lower intensities depending on } \\
\text { the individual's comfort level. } \\
\text { Overall, the music was played } \\
\text { at a moderately loud, but not } \\
\text { uncomfortable level. }\end{array}$ & $\begin{array}{l}\text { This } r \begin{array}{r}\text { study } \\
\text { investigated }\end{array} \\
\text { impact of AIT on } \\
\text { transforming growth } \\
\text { factor (TGF)- } \beta 1 \\
\text { and its effect on } \\
\text { behavioural and } \\
\text { social emotions in } \\
\text { children with ASD. }\end{array}$ & $\begin{array}{l}\text { Plasma levels of TGF- } \beta 1 \\
\text { significantly increased to } 85 \% \\
\text { immediately after AIT ( } 20.13 \\
\pm 12 \mathrm{ng} / \mathrm{mL}, \mathrm{p}<0.05), \text { to } \\
95 \% 1 \mathrm{month} \text { after AIT ( } 21.2 \\
\pm 11 \mathrm{ng} / \mathrm{mL}, \mathrm{p}<0.01) \text {, and } \\
\text { to } 105 \% .3 \mathrm{months} \text { after } \\
\text { AIT }(22.25 \pm 16 \mathrm{ng} / \mathrm{mL}, \mathrm{p}< \\
0.01) \text { compared to before AIT } \\
(10.85 \pm 8 \mathrm{ng} / \mathrm{mL}) \text {. }\end{array}$ & $\begin{array}{l}\begin{array}{l}\text { Results also revealed } \\
\text { that } \\
\text { behavioural }\end{array} \\
\text { rating scales CARS, SRS, } \\
\text { and SSP improved in terms of } \\
\text { symptom severity after AIT. }\end{array}$ & Not specified \\
\hline $\begin{array}{l}\text { Bagatell } \\
\text { et al. ( 2010) }\end{array}$ & \begin{tabular}{|l|} 
Total:6 boys \\
with autism \\
spectrum \\
disorder (ASD), \\
all in first grade
\end{tabular} & $\begin{array}{l}\text { The sensory processing } \\
\text { pattern of each participant was } \\
\text { assessed using the Sensory } \\
\text { Processing Measure that was } \\
\text { scored by the teacher. }\end{array}$ & $\begin{array}{l}\text { The procedure was divided } \\
\text { into stages; all of them were } \\
\text { set in the classroom. Phase A: } \\
\text { Baseline lasted } 5 \text { days used to } \\
\text { collect date during Circle time. } \\
\text { Phase B: Intervention: occurred } \\
\text { over } 9 \text { days during Circle } \\
\text { time but children, teacher, and } \\
\text { instructional aides sat on therapy } \\
\text { ball chairs with a ring stabilizer. } \\
\text { Phase C: Choice. During the final } \\
\text { phase ( } 5 \text { days), the children were } \\
\text { given the choice of sitting on a } \\
\text { regular seating device (chair) or } \\
\text { on a therapy ball chair. }\end{array}$ & $\begin{array}{l}\text { The goal was to } \\
\text { examine classroom } \\
\text { participation- }- \\
\text { specifically, in- } \\
\text { seat behaviour and } \\
\text { engagement and } \\
\text { social validity. }\end{array}$ & $\begin{array}{l}\text { Of the six respondents one } \\
\text { student with ASD showed } \\
\text { the most significant progress } \\
\text { after using the therapeutic } \\
\text { sitting ball, also the higher } \\
\text { degree of participation and } \\
\text { better self-regulation of } \\
\text { sitting behaviour after the } \\
\text { application of therapeutic } \\
\text { sitting balls. }\end{array}$ & $\begin{array}{l}\text { The ball chair appeared to } \\
\text { have a positive effect on in- } \\
\text { seat behaviour for the child } \\
\text { who had the most extreme } \\
\text { vestibular-proprioceptive } \\
\text { seeking behaviours. }\end{array}$ & $\begin{array}{l}\text { The use of the therapy ball } \\
\text { chair did not positively affect } \\
\text { engagement. }\end{array}$ \\
\hline
\end{tabular}




\begin{tabular}{|c|c|c|c|c|c|c|c|}
\hline Citation & $\begin{array}{l}\text { Participant } \\
\text { characteristics }\end{array}$ & Assessment & Intervention/procedure & $\begin{array}{l}\text { The purpose of the } \\
\text { study }\end{array}$ & Results & $\begin{array}{l}\text { There was improvement in } \\
\text { which behaviour }\end{array}$ & $\begin{array}{l}\text { The intervention did not } \\
\text { improve the following } \\
\text { behaviour }\end{array}$ \\
\hline $\begin{array}{l}\text { Bestbier } \\
\& \text { Williams, } \\
(2017)\end{array}$ & $\begin{array}{l}\text { Total: } 13 \\
\text { students; } \\
\text { Gender: } 2 \\
\text { girls and } 13 \\
\text { boys;Gender: } \\
2 \text { girls and } \\
13 \text { boys; Dg.: } \\
8 \text { with ASD } \\
\text { and } 7 \text { ID; Age: } \\
\text { ranged from } 7 \\
\text { yrs and } 10 \text { mths } \\
\text { to } 18 \text { yrs and } \\
7 \text { mths }\end{array}$ & $\begin{array}{l}\text { Pretest-posttest design was } \\
\text { employed to evaluate the } \\
\text { effects of deep pressure } \\
\text { sessions on young people with } \\
\text { ASD and severe intellectual } \\
\text { disabilities. Visual analogue } \\
\text { scale was to measure mood and } \\
\text { activity of the young people by } \\
\text { school staff. }\end{array}$ & $\begin{array}{l}\text { Setting: quiet places with } \\
\text { minimal distraction in the school. } \\
\text { Three deep pressure techniques } \\
\text { were used, by care and education } \\
\text { staff that had been trained by an } \\
\text { occupational therapist with a } \\
\text { sensory integration qualification: } \\
\text { brushing, massage, and } \\
\text { squeezing. The sessions lasted } \\
\text { between five and fifteen minutes, } \\
\text { up to three times per day during } \\
\text { school hours. The deep pressure } \\
\text { was delivered over a period of } \\
\text { three months on weekdays when } \\
\text { the young people were in school. }\end{array}$ & $\begin{array}{l}\text { This study was } \\
\text { designed to provide } \\
\text { information about the } \\
\text { extent of variability } \\
\text { of the immediate } \\
\text { responses of young } \\
\text { people with ASD and } \\
\text { severe intellectual } \\
\text { disability to deep } \\
\text { pressure by providing } \\
\text { regular access to } \\
\text { deep pressure }\end{array}$ & $\begin{array}{l}\text { Results mixed.Four of } \\
\text { the young people showed } \\
\text { benefits in all areas measured, } \\
\text { two showed no benefits in } \\
\text { any area, and further two } \\
\text { showed benefits on three and } \\
\text { two ratings each. }\end{array}$ & $\begin{array}{l}\text { On the Calmness subscale } \\
\text { results indicate improvement } \\
\text { for } 75 \% \text { of the participants. } \\
\text { On the Engaged subscale } \\
\text { results indicate improvement } \\
\text { for } 62.5 \% \text { of the participants. } \\
\text { On the Responsively subscale } \\
\text { results indicate improvement } \\
\text { for } 62.5 \% \text { of the participants. } \\
\text { On the Happy subscale results } \\
\text { indicate improvement for } \\
50 \% \text { of the participants. On } \\
\text { the Communicative subscale } \\
\text { results indicate improvement } \\
\text { for } 62.5 \% \text { of the participants. }\end{array}$ & $\begin{array}{l}\text { On the Calmness subscale } \\
\text { results did not indicate } \\
\text { improvement for the } 25 \% \\
\text { of the participants. On the } \\
\text { Engaged subscale results did } \\
\text { not indicate improvement for } \\
\text { the } 37.5 \% \text { of the participants. } \\
\text { On the Responsively subscale } \\
\text { results did not indicate } \\
\text { improvement for the } 37.5 \% \\
\text { of the participants. On the } \\
\text { Happy subscale results did } \\
\text { not indicate improvement for } \\
50 \% \text { of the participants. On } \\
\text { the Communicative subscale } \\
\text { results did not indicate } \\
\text { improvement for } 37.5 \% \text { of } \\
\text { the participants. }\end{array}$ \\
\hline $\begin{array}{l}\text { Brockett, } \\
\text { et al. (2014) }\end{array}$ & \begin{tabular}{|l} 
Total:54 \\
children \\
Gender: 45 \\
males $(83 \%)$ \\
and 9 females \\
$(17 \%)$. \\
Dg. 35 autism/ \\
PDD-NOS, \\
7 speech/ \\
language \\
disorders, \\
6 sound \\
sensitivity/ \\
auditory \\
processing \\
disorders, 5 \\
ADD, 4 \\
SPD and 5 no \\
diagnostic label \\
Age: $3-10$ years \\
(M 6).
\end{tabular} & $\begin{array}{l}\text { The SSP (Dunn, 1999) } \\
\text { checklist which measures } \\
\text { behavioral response to specific } \\
\text { sensory stimuli that occur } \\
\text { during daily life activities, } \\
\text { such as (1) Tactile Sensitivity, } \\
\text { (2) Taste/Smell Sensitivity, } \\
\text { (3) Movement Sensitivity, } \\
\text { (4) Under-Responsive/Seeks } \\
\text { Sensation, (5) Auditory } \\
\text { Filtering, (6) Low Energy/ } \\
\text { Weak and (7) Visual/Auditory } \\
\text { Sensitivity was completed } \\
\text { by primary care givers. } \\
\text { The ABC behavior rating scale } \\
\text { was used to measure behavior } \\
\text { such as irritability, stereotypic, } \\
\text { lethargy, hyperactivity, } \\
\text { inappropriate speech. }\end{array}$ & $\begin{array}{l}\text { All children participate in a } \\
\text { standard protocol of Berard AIT } \\
\text { that consisted of two 30-minute } \\
\text { sessions of listening each day for } \\
10 \text { consecutive days. With a three- } \\
\text { hour break from the auditory } \\
\text { stimulation between sessions. } \\
\text { Music for Berard AIT is generally } \\
\text { a variety of light rock, reggae, } \\
\text { and jazz, selected specifically } \\
\text { to assure that it contains a wide } \\
\text { range of frequencies from } 20 \mathrm{~Hz} \\
\text { to } 20 \mathrm{kHz} \text {. }\end{array}$ & $\begin{array}{l}\text { The purpose of } \\
\text { this study was } \\
\text { to determine if } \\
\text { behaviors specifically } \\
\text { related to sensory } \\
\text { modulation showed } \\
\text { positive changes } \\
\text { following 10 days of } \\
\text { Berard AIT. }\end{array}$ & $\begin{array}{l}\text { Analysis of variance indicated } \\
\text { that SSP total test scores and } \\
\text { individual factor sections } \\
\text { improved from pretest to } \\
\text { post-test (P 0.01). Behavioral } \\
\text { problems reduced on all } \\
\text { five factors of the Aberrant } \\
\text { Behavior Checklist (ABC) } \\
(\mathrm{P} 0.01) \text { Most changes } \\
\text { occurred within one month of } \\
\text { intervention and maintained } \\
\text { at three and six months. } \\
\text { Correlations among the ABC } \\
\text { and SSP factors indicate } \\
\text { that sensory modulation as } \\
\text { measured by the SSP is a } \\
\text { significant contributor to } \\
\text { four of the behavioral factors } \\
\text { measured by the ABC. }\end{array}$ & $\begin{array}{l}\text { The children's results } \\
\text { improved in the following } \\
\text { domains: tactile sensitivity, } \\
\text { taste/smell sensitivity, } \\
\text { movement sensitivity, under- } \\
\text { responsively, auditory filtering, } \\
\text { low energy/weak, and visual/ } \\
\text { auditory sensitivity. The } \\
\text { results measured on ABC } \\
\text { scale indicate improvement } \\
\text { in following domains: } \\
\text { irritability, lethargy, stereotypy, } \\
\text { hyperactivity, inappropriate } \\
\text { speech. }\end{array}$ & Not specified \\
\hline
\end{tabular}




\begin{tabular}{|c|c|c|c|c|c|c|c|}
\hline Citation & \begin{tabular}{|l|} 
Participant \\
characteristics
\end{tabular} & Assessment & Intervention/procedure & \begin{tabular}{|l|} 
The purpose of the \\
study
\end{tabular} & Results & $\begin{array}{l}\text { There was improvement in } \\
\text { which behaviour }\end{array}$ & $\begin{array}{l}\text { The intervention did not } \\
\text { improve the following } \\
\text { behaviour }\end{array}$ \\
\hline $\begin{array}{l}\text { Iwanaga } \\
\text { et al. (2014) }\end{array}$ & \begin{tabular}{|l|} 
Total: 20 \\
children; \\
Gender: 18 \\
males and 2 \\
females. \\
Dg. 9 autism \\
and 11 \\
Asperser's \\
syndrome \\
Average age 4.7 \\
years.
\end{tabular} & $\begin{array}{l}\text { JMAP (Tsuchida et al., 1989), } \\
\text { a re-standardized version of } \\
\text { the Miller Assessment for } \\
\text { Preschoolers (MAP) for use } \\
\text { with Japanese children was } \\
\text { used to measure five major } \\
\text { developmental indices: } \\
\text { 1) Foundation Index; 2) } \\
\text { Coordination Index; 3) Verbal } \\
\text { Index;4) Non-verbal Index; and } \\
\text { 5) Complex Index. A trained } \\
\text { practitioner administered the } \\
\text { test individually before and } \\
\text { after the treatment. }\end{array}$ & $\begin{array}{l}8 \text { children received individual } \\
\text { SIT and } 12 \text { children received } \\
\text { group therapy (GT). } 17 \text { of the } \\
\text { subjects were treated in Nagasaki } \\
\text { Prefectural Medical Treatment } \\
\text { and Education Centre. Twelve } \\
\text { children of them received GT and } \\
\text { five received SIT. Three children } \\
\text { who received SIT were treated in } \\
\text { the clinic at Nagasaki University. } \\
\text { Durations of SIT and GT were } \\
\text { between } 8 \text { to } 10 \text { months. SIT } \\
\text { included the } 10 \text { key therapeutic } \\
\text { strategies identified by Parham et } \\
\text { al. (2007). }\end{array}$ & $\begin{array}{l}\text { The aim was } \\
\text { to examine the } \\
\text { effectiveness of SIT } \\
\text { on cognition, verbal, } \\
\text { and sensory motor } \\
\text { abilities in children } \\
\text { with ASD. }\end{array}$ & 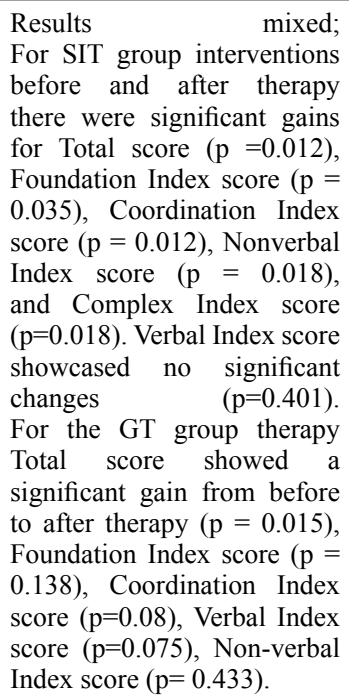 & $\begin{array}{l}\text { Improvement in both groups } \\
\text { in the domain of fine and } \\
\text { gross motor skills, oral } \\
\text { motor and visual-motor } \\
\text { abilities, nonverbal memory, } \\
\text { sequencing, visualization, } \\
\text { solving complex problems } \\
\text { that require the engagement of } \\
\text { certain cognitive and sensory- } \\
\text { motor abilities. }\end{array}$ & $\begin{array}{l}\text { Verbal abilities have not } \\
\text { significantly improved. }\end{array}$ \\
\hline $\begin{array}{l}\text { Kashefimehr, } \\
\text { et al. (2017) }\end{array}$ & $\begin{array}{l}\text { Total: } 35 \\
\text { children; } \\
\text { Gender: } 28 \\
\text { boys and } 3 \\
\text { girls; } \\
\text { DG. ASD } \\
\text { Age: } 3 \text { to } 8 \\
\text { years } \backslash\end{array}$ & $\begin{array}{l}\text { The Short Child Occupational } \\
\text { Profile (SCOPE, Kielhofner, } \\
\text { 2002) was used to compare } \\
\text { the two groups in terms of the } \\
\text { changes in their occupational } \\
\text { performance and the Sensory } \\
\text { Profile (SP, Dunn, 1999) } \\
\text { was used to assess sensory } \\
\text { problems. The study used a pre } \\
\text { and post test design. }\end{array}$ & $\begin{array}{l}\text { The children were divided } \\
\text { into two groups intervention } \\
\text { group (n }=16) \text { receiving SIT } \\
\text { and a control group (n }=15) \text {. } \\
\text { SIT was described as a clinic- } \\
\text { based intervention that uses play } \\
\text { activities and sensory-enhanced } \\
\text { interactions to elicit the child's } \\
\text { adaptive responses. In this } \\
\text { intervention, the therapist creates } \\
\text { activities that encourage the } \\
\text { child's participation and challenge } \\
\text { his sensory processing and motor } \\
\text { planning skills following the } \\
\text { 10 key therapeutic strategies } \\
\text { identified by Parham et al. (2007). } \\
\text { Each participant in the } \\
\text { intervention group received 24 } \\
\text { SIT (two per week), each } 45 \text { min. } \\
\text { in length with an additional 15 } \\
\text { Min. devoted to parent education. } \\
\text { No information was given about } \\
\text { the control group. }\end{array}$ & $\begin{array}{l}\text { This study examined } \\
\text { the effect of SIT on } \\
\text { different aspects } \\
\text { of occupational } \\
\text { performance in } \\
\text { children with ASD. }\end{array}$ & $\begin{array}{l}\text { Results showed that } \\
\text { significant difference were } \\
\text { observed in SCOPE domains } \\
\text { in pre intervention data but } \\
\text { a significant difference was } \\
\text { observed between the two } \\
\text { groups in terms of the sensory } \\
\text { seeking, sensory sensitivity, and } \\
\text { behavioral outcomes }(\mathrm{p}<.05) \text {. } \\
\text { A significantly } \\
\text { greater improvement } \\
\text { was observed in the } \\
\text { intervention group in all } \\
\text { domains of SCOPE including } \\
\text { volition, habituation, } \\
\text { communication and interaction } \\
\text { skills, process skills, motor } \\
\text { skills, and environment of } \\
\text { occupational performance and } \\
\text { also in the total score of the } \\
\text { child (p < 0.001). Of the 35 } \\
\text { ASD children participating in } \\
\text { the study, 31 (88.6\%) showed } \\
\text { difference in sensory profile } \\
\text { according to SP. }\end{array}$ & $\begin{array}{l}\text { The intervention group } \\
\text { showed significantly greater } \\
\text { improvement in all the SCOPE } \\
\text { domains, as well as in some of } \\
\text { the SP domains }\end{array}$ & $\begin{array}{l}\text { There was not improvement } \\
\text { on the SP scale for the } \\
\text { "emotional reactions" and } \\
\text { "emotional/social responses" } \\
\text { domains, }(\mathrm{p}<.05) \text {. }\end{array}$ \\
\hline
\end{tabular}




\begin{tabular}{|c|c|c|c|c|c|c|c|}
\hline Citation & $\begin{array}{l}\text { Participant } \\
\text { characteristics }\end{array}$ & Assessment & Intervention/procedure & $\begin{array}{l}\text { The purpose of the } \\
\text { study }\end{array}$ & Results & $\begin{array}{l}\text { There was improvement in } \\
\text { which behaviour }\end{array}$ & $\begin{array}{l}\text { The intervention did not } \\
\text { improve the following } \\
\text { behaviour }\end{array}$ \\
\hline $\begin{array}{l}\text { Pfeiffer } \\
\text { et al. (2011) }\end{array}$ & $\begin{array}{l}\text { Type of sample: } \\
\text { convenient. } \\
\text { Total: } 37 \\
\text { children; } \\
\text { Gender: } 32 \\
\text { males and } 5 \\
\text { females, } \\
\text { Dg.: } 21 \text { had } \\
\text { autism and } 16 \\
\text { with PDD- } \\
\text { NOS. } \\
\text { Ages between } \\
6 \text { and } 12 \text { (mean } \\
\text { [M] age } 58.8 \text { ). }\end{array}$ & $\begin{array}{l}\text { All assessments were used } \\
\text { as a pre and post test and } \\
\text { were carried out by parents } \\
\text { and clinicians, who were not } \\
\text { aware of the group assessment. } \\
\text { Sensory Processing Measure } \\
\text { was used to measure sensory } \\
\text { processing disorders. } \\
\text { QNST-II (Mutti et al., 1998) } \\
\text { was used to assess areas } \\
\text { including praxis, dexterity, } \\
\text { visual tracking, spatial } \\
\text { orientation, tactile perception } \\
\text { abilities, and motor skills.Social } \\
\text { Responsiveness Scale was used } \\
\text { to measure social impairments. } \\
\text { Goal Attainment Scaling was } \\
\text { used to determine intervention } \\
\text { outcomes expressly relevant } \\
\text { to individuals and their } \\
\text { families. The goals focused } \\
\text { on the three categories of } \\
\text { sensory processing, motor } \\
\text { skills, and social functioning. } \\
\text { Vineland Adaptive Behavior } \\
\text { Scales, 2nd Edition was used } \\
\text { to measure adaptive behaviors } \\
\text { that assess the domains of } \\
\text { communication, daily living } \\
\text { skills, socialization, and motor } \\
\text { skills. }\end{array}$ & $\begin{array}{l}\text { Two interventions SIT and fine } \\
\text { motor intervention (FMT). } \\
\text { Participants were randomly } \\
\text { assigned } 20 \text { undergone SIT and } 17 \\
\text { FMT intervention- control group. } \\
\text { Both interventions consisted } \\
\text { of } 18 \text { treatment interventions } \\
\text { of } 45 \text { min each over a } 6-w k \\
\text { period, SIT included the } 10 \mathrm{key} \\
\text { therapeutic strategies identified } \\
\text { by Parham et al. (2007). } \\
\text { FMT focused on three main } \\
\text { activity areas: constructional, } \\
\text { drawing and writing, and FM } \\
\text { crafts. }\end{array}$ & $\begin{array}{l}\text { Was to address } \\
\text { the question of } \\
\text { effectiveness of } \\
\text { SI interventions in } \\
\text { children with ASD. }\end{array}$ & $\begin{array}{l}\text { Results were mixed. Both } \\
\text { SIT and FMT groups had } \\
\text { significant improvements } \\
\text { toward goals on the GAS, } \\
\text { but SIT demonstrated more } \\
\text { significant improvement } \\
\text { than the FM group in the } \\
\text { attainment of goals as rated } \\
\text { by parents }(\mathrm{p}<.05 \text {, ) and } \\
\text { teachers }(\mathrm{p}<.01) \text {. }\end{array}$ & $\begin{array}{l}\text { Improvements were registered } \\
\text { in significantly fewer autistic } \\
\text { mannerisms in SIT group than } \\
\text { in FMT group. }\end{array}$ & \begin{tabular}{|lr}
\multicolumn{2}{|l}{ In both groups no significant } \\
differences & were found \\
processing & standardized \\
scores. &
\end{tabular} \\
\hline $\begin{array}{l}\text { Thompson } \\
\text { (2011) }\end{array}$ & $\begin{array}{l}\text { Sample type: } \\
\text { random. } \\
\text { Total: } 50 \\
\text { participants, } \\
\text { Gender: } 26 \\
\text { female students } \\
\text { and } 24 \text { male } \\
\text { students } \\
\text { Dg.: } 10 \text { of them } \\
\text { had autism, } \\
32 \text { intellectual } \\
\text { disabilities } \\
\text { and } 8 \text { children } \\
\text { with multiple } \\
\text { disabilities. } \\
\text { Age: from } 6 \\
\text { to } 17 .\end{array}$ & $\begin{array}{l}\text { The authors created an } \\
\text { observation system to measure } \\
\text { sustained focus. }\end{array}$ & $\begin{array}{l}\text { Observations were conducted by } \\
\text { trained observers stationed within } \\
\text { secluded locations in the regular } \\
\text { classrooms and multi-sensory } \\
\text { centre. Students were observed } \\
\text { individually within three types } \\
\text { of environments and during } \\
\text { three time periods: (1) initial } \\
\text { observations was conducted } \\
\text { within the regular classroom } \\
\text { before treatment; (2) during } \\
\text { the multi-sensory intervention; } \\
\text { and (3) after the multi-sensory } \\
\text { intervention in the classroom. }\end{array}$ & $\begin{array}{l}\text { Was to examine the } \\
\text { observed impact } \\
\text { of multi-sensory } \\
\text { experiences on the } \\
\text { sustained focus of } \\
\text { students with special } \\
\text { needs. }\end{array}$ & $\begin{array}{l}\text { Generally results were } \\
\text { positive, the ability to } \\
\text { maintain attention in } \\
\text { learning conditions (during } \\
\text { class) increased by } 14 \%, \\
\text { while the manifestation of } \\
\text { auto-aggressive behavior } \\
\text { decreased by 98\%. Also, } \\
\text { the feeling of happiness, } \\
\text { relaxation and the level of } \\
\text { participation in the class } \\
\text { increased significantly } \\
\text { after the treatment in all } \\
\text { respondents. }\end{array}$ & Not specified & Not specified \\
\hline
\end{tabular}




\begin{tabular}{|c|c|c|c|c|c|c|c|}
\hline Citation & $\begin{array}{l}\text { Participant } \\
\text { characteristics }\end{array}$ & Assessment & Intervention/procedure & $\begin{array}{l}\text { The purpose of the } \\
\text { study }\end{array}$ & Results & $\begin{array}{l}\text { There was improvement in } \\
\text { which behaviour }\end{array}$ & $\begin{array}{l}\text { The intervention did not } \\
\text { improve the following } \\
\text { behaviour }\end{array}$ \\
\hline $\begin{array}{l}\text { Wenix } \\
\text { et al. (2019) }\end{array}$ & $\begin{array}{l}\text { Sample type; } \\
\text { convenient. } \\
\text { Total:108 } \\
\text { participants; } \\
\text { Gender: } 88 \text { male } \\
\text { and } 15 \\
\text { Dg. autism } \\
\text { The participants } \\
\text { were divided } \\
\text { into group A } \\
\text { and B. } \\
43 \text { male patients } \\
\text { and } 7 \text { female } \\
\text { patients with an } \\
\text { average age of } \\
6.17 \pm 2.44 \text { were } \\
\text { included in } \\
\text { group A. } \\
45 \text { male patients } \\
\text { and } 8 \text { female } \\
\text { patients with an } \\
\text { average age of } \\
6.18 \pm 2.94 \text { were } \\
\text { included in } \\
\text { group }\end{array}$ & $\begin{array}{l}\text { CARS scale was used to } \\
\text { measure interpersonal } \\
\text { relationships, emotional } \\
\text { responses, adaptation to } \\
\text { environmental changes, visual } \\
\text { responses, anxiety responses, } \\
\text { non-verbal communication, and } \\
\text { so on. Autistic Behavior Check } \\
\text { List (ABC List) (Lu et al. } \\
\text { 2004) was used to determine if } \\
\text { a child had autism. }\end{array}$ & $\begin{array}{l}\text { Participants were randomly } \\
\text { divided into group A (SIT } \\
+ \text { routine treatment group) } \\
\text { and group B (routine } \\
\text { treatment group), each } \\
\text { group had } 54 \text { members. } \\
\text { Evaluation was carried out before } \\
\text { and after the experiment, and } \\
\text { the scales were filled in under } \\
\text { the guidance of professionals. } \\
\text { SIT method uses games such } \\
\text { as slides, tossing, leaping, } \\
\text { balance beam, and sling } \\
\text { to train children's balance, } \\
\text { communication, and brain } \\
\text { integration functions. }\end{array}$ & $\begin{array}{l}\text { The aim was } \\
\text { to examine the } \\
\text { joint effect of } \\
\text { SIT and exercise } \\
\text { intervention on } \\
\text { the behaviors and } \\
\text { quality of life of } \\
\text { children with autism. }\end{array}$ & 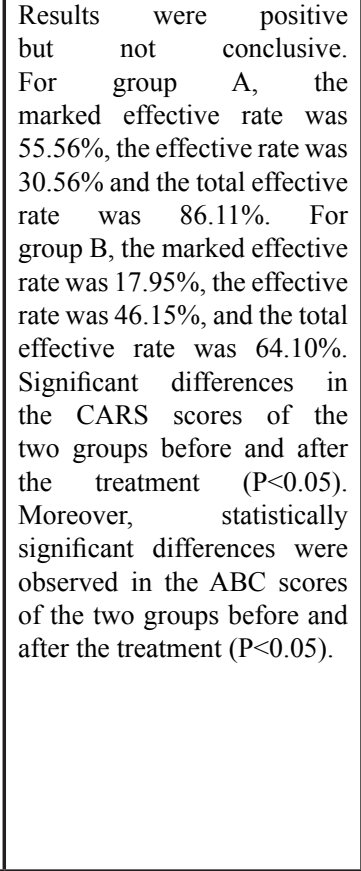 & $\begin{array}{l}\text { The sensory, language, } \\
\text { communication, self-care, } \\
\text { and physical exercise } \\
\text { ability of the experiment } \\
\text { group significantly improved } \\
\text { after the intervention period. } \\
\text { The difference with the } \\
\text { control group after the } \\
\text { intervention is statistically } \\
\text { significant }(\mathrm{P}<0.01) \text {. } \\
\text { ABC score of the experiment } \\
\text { group has exhibited } \\
\text { significantly lower score } \\
\text { than before the intervention. } \\
\text { However, a significant decline } \\
\text { was observed in the ABC score } \\
\text { of the control group. Further } \\
\text { differential analysis suggests } \\
\text { that the decline in the ABC } \\
\text { score of the control group is } \\
\text { significantly lower than that of } \\
\text { the experiment group. }\end{array}$ & Not specified \\
\hline
\end{tabular}




\section{Intervention procedure:}

Five of the ten studies presented in this paper focused on examining the effects of sensory integration therapy on cognition, verbal and sensorimotor abilities (Iwanaga et al., 2014), various aspects of occupational performance (Kashefimehr, et al., 2017), on the sustained focus (Thompson, 2011), behavior and quality of life of children with ASD (Wenix et al., 2019; Pfeiffer et al., 2011). Three of these studies included 10 key therapeutic strategies identified by Parham et al. (2007) (Iwanaga et al., 2014; Kashefimehr, et al., 2017; Pfeiffer et al., 2011), while the authors of the remaining two studies did not specify the sensory integration methods they applied (Thompson, 2011; Wenix et al., 2019).

Three studies were conducted to determine the effectiveness of auditory integration training in children with ASD (Al-Ayadhi et al., 2013) and the effects of this training on the behavior and social and emotional development of children with ASD (Al-Ayadhi et al. 2018). One of these studies focused on the impact of auditory integration training on behaviors directly related to sensory modulation problems in children with ASD (Brockett, et al., 2014).

One study involved alternative seating on therapy ball chairs in order to improve classroom participation, more specifically on in-seat behavior and engagement and social validity (Bagatell et al., 2010).

Finally, deep pressure therapy was used in one study to examine the effects of this therapy on the responsiveness of children with ASD and deep ID (Bestbier \& Williams, 2017).

Eight studies conducted pre- and post-intervention evaluation (Al-Ayadhi et al., 2013; Al-Ayadhi et al., 2018; Bagatell et al., 2010; Bestbier \& Williams, 2017; Iwanaga et al., 2014; Kashefimehr, et al., 2017; Pfeiffer et al., 2011; Wenix et al., 2019).

\section{Results/improvements in behavior:}

The results of the presented studies, focused on examining the effects of sensory integration therapy, indicate a significant positive impact of this type of intervention. After SI therapy progress has been noted in various domains: motor skills (Kashefimehr et al., 2017) - fine and gross motor skills, oral motor and visual-motor abilities (Iwanaga et al., 2014; Pfeiffer et al., 2011); sensory processing (Pfeiffer et al., 2011) nonverbal memory, sequencing, visualization, solving complex problems that require the engagement of certain cognitive and sensory-motor abilities (Iwanaga et al., 2014), adaptive behavior, social functioning (Pfeiffer et al., 2011) communication and interaction skills, environment of occupational performance (Kashefimehr et al., 2017), attention (Thompson, 2011).

Results show increase in the ability to maintain attention in learning conditions by $14 \%$, and $98 \%$ decrease in auto-aggressive behavior in children with ASD after SIT (Thompson, 2011). Also, there is a noticeable difference in pre- and post-treatment scores on CARS and $\mathrm{ABC}$ which indicates a decline in autism specific behavior (Wenix et al., 2019). Positive changes in the sensory profile of children with ASD after SIT are also noticeable (Kashefimehr et al., 2017). On the other hand, no significant improvement was registered in verbal abilities (Iwanaga et al., 2014) and in the emotional domain - emotional reactions and emotional/social responses (Kashefimehr et al., 2017).

In the case of auditory integration training, pre- and post-evaluation results indicate improvement in social awareness, social cognition, and social communication (Al-Ayadhi et al., 2013), as well as improved scores on CARS, SRS, SSP, and ABC which indicate decline in condition severity and improvement in adaptive behavior after AIT (Al-Ayadhi et al., 2018; Brockett, et al., 2014). Changes in the sensory profile are reflected in the following domains: tactile sensitivity, taste/ smell sensitivity, movement sensitivity, under-responsively, auditory filtering, low energy/weak, and visual/auditory sensitivity (Brockett, et al., 2014). On the other hand, positive behavioral changes are registered in the following domains: irritability, lethargy, stereotypy, hyperactivity, inappropriate speech. The results showed that most changes occurred within one month of intervention and maintained at three and six months (Al-Ayadhi et al., 2013; Al-Ayadhi et al., 2018; Brockett, et al., 2014). No improvement was registered in the domain of social motivation and stereotypical behavior, as well as in sensory and cognitive domain (AlAyadhi et al., 2013).

One study used therapeutic ball chairs to examine the effects of an alternative form of sitting on participation of student with ASD. The results of this study indicate that children with vestibular-proprioceptive seeking behaviors have benefited the most from this type of sitting. Significant progress is noticed in self-regulation of sitting behavior and participation in learning activities (Bagatell et al., 2010).

The use of deep pressure techniques (brushing, massage, and squeezing) has been shown to increase calmness $(75 \%)$, engagement with activities $(62.5 \%)$, responsiveness to instructions or other stimuli in the environment $(62.5 \%)$, happiness $(50 \%)$ and communicativeness (62.5\%) in students with ASD and severe ID (Brockett, et al., 2014). However, the results of this research are mixed, maybe due to the fact that all participants received a different number of interventions on a weekly basis.

Based on the ten reviewed studies we can conclude that in people with ASD the most common difficulties are sensory processing of auditory stimuli and that sensory profiles are extremely heterogeneous. Because of this heterogeneous of sensory profiles and the lack of same methods used for SIT interventions we cannot conclude that this form of therapy is scientifically based. 


\section{CONCLUSIONS}

The results of the analyzed studies indicate a remarkable heterogeneity profile of sensory function in children with ASD, which affect the applicability of different forms of treatment. Treatments based on the theory of SI are aimed at reducing or eliminating the difficulties of SI, which stimulates the cognitive and social development of the child with ASD, and thus affects the educational process and educational inclusion. Most of the research presented in this paper focuses on the influence of different forms of treatment on different domains of behavior of a child with ASD. Based on the results of these studies, we can conclude that treatments based on SI theory can reduce stereotypical, aggressive, auto-aggressive, irritable and hyperactive behavior, as well as improve self-regulation of behavior. The significance of these changes in the school environment is reflected in the increased possibility of active participation of children with ASD and the reduction of social distance of peers and other persons towards children with ASD, which supports the process of educational and social inclusion.

All research presented in this paper focuses on the effects of SI treatment on the functioning of children with ASD. The obtained findings indicate a positive influence of SIT, AIT and DPT on certain domains of functioning of children with ASD. The variability of the effects of these treatments in children with different sensory disorders indicates the need to create individualized treatment programs and combine different methods and techniques to encourage SI to provide adequate treatment tailored to the specific difficulties and abilities of each individual child. By hindering the daily functioning of a child with ASD, SI difficulties limit the possibility of participation of students with ASD in school activities, can lead to the creation and increase of social distance towards these students, hinder the process of adopting materials and, thus, require significant adjustments of curriculum and methods. Reducing or eliminating sensory difficulties has a positive impact on cognitive and social development, as well as on student's behavior, which conditions the better functioning of the individual with ASD both in the school environment and in the community. Therefore, it is necessary to conduct a more detailed analysis of sensory profiles of students with ASD, creating adequate instruments for assessment and monitoring, as well as examining the effectiveness of different SI treatments depending on the sensory difficulties of students with ASD. Ethnological aspects, typical for the environment of the child, can be included in therapeutically processes, such as movement, dance and music background in sensor-motor performance of the child.

\section{REFERENCES}

Al-Ayadhi, L. Y., Al-Drees, A. M., \& Al-Arfaj, A. M. (2013). Effectiveness of auditory integration therapy in autism spectrum disorders - prospective study. Autism Insights, 5, 13-20.

Ayres, F., \& Ault, J. (1972). Schaum's outline of theory and problems of differential equations in SI metric units. London: McGraw-Hill.

Ayres, A. J. \& Robbins, J. (2005). Sensory integration and the child: Understanding hidden sensory challenges. Western Psychological Services.

Bagatell, N., Mirigliani, G., Patterson, C., Reyes, Y., \& Test, L. (2010). Effectiveness of therapy ball chairs on classroom participation in children with autism spectrum disorders. American Journal of Occupational Therapy, 64(6), 895-903.

Baker, A. E., Lane, A., Angley, M. T., \& Young, R. L. (2008) The relationship between sensory processing patterns and behavioral responsiveness in autistic disorder: A pilot study. Journal of Autism and Developmental Disorders, 38(5), 867-875.

Bayne, T. (2014). The multisensory nature of perceptual consciousness. In D. J. Bennett \& C. S. Hill (Eds.): Sensory Integration and the Unity of Consciousness (pp. 15-36). MIT Press.

Bestbier, L. \& Williams, T. I. (2017). The Immediate Effects of Deep Pressure on Young People with Autism and Severe Intellectual Difficulties: Demonstrating Individual Differences. Occupational Therapy International, 2017, Article ID 7534972, 7 pages, 2017

Bojanin, S. (2015). Tretman pokretom i savetovanje: Reedukacija psihomotorike, relaksacija psihomotorike (Šulc, Beržez), pokret u psihoterapiji. Beograd - Pomoć porodici.

Boterberg, S. \& Warreyn, P. (2016). Making sense of it all: The impact of sensory processing sensitivity on daily functioning of children. Personality and Individual Differences, 92, 8086.

Brockett, S. S., Lawton-Shirley, N. K., \& Kimball, J. G. (2014). Berard auditory integration training: Behavior changes related to sensory modulation. Autism Insights, 6, 1.

Dunn, W. (1997). The impact of sensory processing abilities on the daily lives of young children and their families: A conceptual model. Infants and Young Children, 9, 23-35.

Gal, E., Dyck, M. J., \& Passmore, A. (2010). Relationships between stereotyped movements and sensory processing disorders in children with and without developmental or sensory disorders. American Journal of Occupational Therapy, 64(3), 453-461.

Gonthier, C., Longuépée, L., \& Bouvard, M. (2016). Sensory processing in low-functioning adults with autism spectrum disorder: Distinct sensory profiles and their relationships with behavioral dysfunction. Journal of Autism and Developmental Disorders, 46(9), 3078-3089.

Hainaut, J.-P. \& Bolmont, B. (2013). Sensory modalities processing in sensorimotor tasks depends on state and trait anxiety. In R. Bruner \& M. Voisin (Eds.): New Developments in Sensory Processing Research (pp. 83-108). New York: Nova Science Publishers, Inc.

Iwanaga, R., Honda, S., Nakane, H., Tanaka, K., Toeda, H., \& Tanaka, G. (2014). Pilot Study: Efficacy of Sensory Integration Therapy for Japanese Children with HighFunctioning Autism Spectrum Disorder. Occupational therapy international, 21(1), 4-11.

Jirikowic, T., Olson, H. C., \& Kartin, D. (2008). Sensory processing, school performance, and adaptive behavior of young schoolage children with fetal alcohol spectrum disorders. Physical \& Occupational Therapy in Pediatrics, 28(2), 117-136.

Macesic-Petrovic, D. (2014). Metodski pristupi rehabilitaciji osoba sa teškoćama u mentalnom funkcionisanju. Univerzitet $\mathrm{u}$ Beogradu - Fakultet za specijalnu edukaciju i rehabilitaciju, Izdavački centar Fakulteta. 
Mamic, D. i Fulgosi Masnjak, R. (2010). Poticanje senzorne integracije kod učenika $\mathrm{s}$ autizmom slušnim integracijskim treningom-Mozart efekt. Hrvatska Revija za Rehabilitacijska Istraživanja, 46(1), 57-68.

Mamic, D., Fulgosi Masnjak, R., i Pintaric Mlinar, L. (2010). Senzorna integracija u radu s učenicima s autizmom. Napredak: Casopis za Pedagogijsku Teoriju $i$ Praksu, 151(1), 69-84.

Matsushima, K. \& Kato, T. (2013). Social interaction and atypical sensory processing in children with autism spectrum disorders. Hong Kong Journal of Occupational Therapy, 23(2), 89-96.

Novakovic, N., Pejovic-Milovancevic, M., Dukic-Dejanovic, S., Paunovic, N., Jordanov, P., \& Vukovic, M. (2015). The relationship between sensory processing and anxiety on CARS scale in autism spectrum disorder. Psihijatrija Danas, 47(2), 139-150.

Panzeri, S., Harvey, C. D., Piasini, E., Latham, P. E., \& Fellin, T. (2017). Cracking the neural code for sensory perception by combining statistics, intervention, and behavior. Neuron, 93(3), 491-507.

Pfeiffer, B. A., Koenig, K., Kinnealey, M., Sheppard, M., \& Henderson, L. (2011). Effectiveness of sensory integration interventions in children with autism spectrum disorders: A pilot study. American Journal of Occupational Therapy, 65(1), 76-85.

Sanz-Cervera, P., Pastor-Cerezuela, G., Fernández-Andrés, M. I., \& Tárraga-Mínguez, R. (2015). Sensory processing in children with Autism Spectrum Disorder: Relationship with non-verbal IQ, autism severity and Attention Deficit/ Hyperactivity Disorder symptomatology. Research in Developmental Disabilities, 45-46, 188-201.

Sobocko, K. \& Zelenski, J. M. (2015). Trait sensory-processing sensitivity and subjective well-being: Distinctive associations for different aspects of sensitivity. Personality and Individual Differences, 83, 44-49.

Thompson, C. J. (2011). Multi-Sensory Intervention Observational Research. International Journal of Special Education, 26(1), 202-214.

Tomchek, S. D. \& Dunn, W. (2007). Sensory processing in children with and without autism: A comparative study using the short sensory profile. American Journal of Occupational Therapy, 61(2), 190-200.

Van Dam, V. C. J., Parise, C. V., \& Ernst, M. O. (2014). Modeling multisensory integration. In D. J. Bennett \& C. S. Hill (Eds.): Sensory Integration and the Unity of Consciousness (pp. 209-229). MIT Press.

\section{FUNDING}

This paper was realized with the support of the Ministry of Education, Science and Technological Development of the Republic of Serbia, according to the Agreement on the realization and financing of scientific research. 